\title{
Nitric Oxide Synthase, Inducible
}

National Cancer Institute

\section{Source}

National Cancer Institute. Nitric Oxide Synthase, Inducible. NCI Thesaurus. Code C38565.

Nitric oxide synthase, inducible (1153 aa, $\sim 131 \mathrm{kDa})$ is encoded by the human NOS2A

gene. This protein is involved in both nitric oxide biosynthesis and arginine metabolism. 